\title{
Nanoselenium as a Growth Promoting Feed Supplement in Broiler Chickens
}

\author{
P. Visha ${ }^{1 *}$, P. Selvaraj ${ }^{2}$ and S. Jayachandran ${ }^{3}$ \\ ${ }^{1}$ Department of Veterinary Physiology and Biochemistry, Veterinary College and Research \\ Institute, Orathanadu, Thanjavur, India \\ ${ }^{2}$ Department of Veterinary Physiology, ${ }^{3}$ Department of Veterinary Biochemistry, Veterinary \\ College and Research Institute, Namakkal-637002, India \\ *Corresponding author
}

\section{Keywords \\ Broiler chickens, Nanoselenium, Body weight gain, Feed conversion ratio}

Article Info

Accepted: 26 April 2020 Available Online: 10 May 2020

\section{A B S T R A C T}

Selenium is an essential nutritional trace element having vital role in immunoprotection, antioxidant defence system, muscle metabolism, growth and reproduction. Hence dietary selenium supplementation in the poultry has been regularly practiced using the inorganic and organic forms. These forms have the limitations of having narrow margin of safety and non specific binding to tissue proteins, hence an alternate form of selenium i.e. nano selenium having greater potential as poultry and livestock feed supplement with higher bioavailability, higher margin of safety and seven fold lower acute toxicity was prepared using starch, ascorbic acid and bovine serum albumin. The nanoselenium $(15-40 \mathrm{~nm})$ synthesized were characterized by XRD analysis, transmission electron microscopy and UV spectrophotometry. This nanoselenium was used for the biological trial in broiler chickens owing to simplicity and easy adaptability for large scale production. The treatment groups were supplemented with $0.3 \mathrm{mg} / \mathrm{kg}$ sodium selenite (T2), $0.3 \mathrm{mg} / \mathrm{kg}$ organic selenium (T3), nanoselenium at three levels viz.0.15 (T4), and 0.3 (T5) and 0.6 $\mathrm{mg} / \mathrm{kg}$ (T6) and T1 group was the control, fed with the basal diet alone. The weekly body weight of individual bird was recorded upto the end of sixth week. The mean body weight gain $(\mathrm{g})$ recorded at the end of $6^{\text {th }}$ week were $2050.35,2108.40,2117.58,2136.50$ and 2141.65 for the groups T2 to T6, respectively when compared to 2030.60 of T1 group. The mean body weight gain at the end of $6^{\text {th }}$ week was higher $(p<0.05)$ in the organic and nanoselenium supplemented groups compared to control. All the nanoselenium supplemented groups (T4, T5 and T6) showed significantly higher $(\mathrm{p}<0.05)$ body weight gain than T1 from $4^{\text {th }}$ week onwards. The T5 and T6 groups supplemented with nanoselenium at $0.3 \mathrm{mg} / \mathrm{kg}$ and $0.6 \mathrm{mg} / \mathrm{kg}$ showed significantly $(\mathrm{p}<0.05)$ increased body weight gain than the groups T1, T2, T3 and T4. The mean body weight gain of T3 did not differ from T4. Hence supplementing the nanoselenium $(0.3-0.6 \mathrm{mg} / \mathrm{kg}$ diet $)$ resulted in increased body weight in broiler chickens with minimal risk of toxicity and better bioavailability. 


\section{Introduction}

Intensive rearing of broiler chickens faces challenges such as high metabolic demand, disease susceptibility, physical stress and inadequate micronutrients and trace minerals. These stressors are responsible for causing immunosuppression. Incompetency of the immune system increases susceptibility to various infectious diseases resulting in decreased productive performance of the birds. These stress factors disrupt the delicate critical balance existing between antioxidant defense system and repair mechanisms in tissues, thus generating free radicals leading to tissue damage. Higher level of free radical accumulation in tissues damages the cell membrane and DNA and thereby depresses growth rate (Morrissey and O' Brien, 1998).

Glutathione peroxidase, thioredoxin reductase, reduced glutathione and tissue thiols are endogenous antioxidant systems which provide defense against free radicals in tissues. Owing to the faster growth rate in broiler chickens, production of endogenous antioxidant systems is insufficient to scavenge the free radicals. Hence, various synthetic and natural antioxidants are being added in the poultry diet (Godin and Wohaieb, 1988).

Trace minerals like selenium are added to the diet of broiler chickens to enhance the antioxidant, immune statues and overall growth performance.

Selenium has a wide range of biological functions in the body (NRC, 1994). Dietary antioxidants such as selenium is important in protecting against the free radical generation, oxidative stress and tissue damage as it is a vital component of selenoenzymes such as glutathione peroxidase, phospholipid peroxidase and thioredoxin reductase (Arner and Holmgren, 2000; Surai, 2000).
Currently, sodium selenite $\left(\mathrm{Na}_{2} \mathrm{SeO}_{3}\right)$ and selenate $\left(\mathrm{Na}_{2} \mathrm{SeO}_{4}\right)$ as inorganic form, and selenium enriched yeast (SY) as organic form are being used as commercial selenium supplements in animal and poultry diets (FDA, 2002).

Compared to organic form of selenium, the inorganic selenium salts have inherent toxicity and low bioavailability. Because of these properties, inorganic selenium salts cannot be added in the diet more than the recommended level, though more selenium is required during stress and disease conditions. Hence, the organic selenium in the form of SeMet and selenium enriched yeast is used in nutritional supplements due to their excellent bioavailability and lower acute toxicity among various selenium forms (Schrauzer, 2003). But as SeMet can be nonspecifically incorporated into proteins in place of methionine, concerns have been raised that SeMet could potentially cause accumulation of selenium in tissues to toxic levels (Waschulewski and Sunde, 1988). Thus, exploring a cost effective selenium source with high bioavailability and low toxicity is necessary.

In this regard, nanotechnological approaches in trace mineral nutrition allows intervention in the absorption process in biological system as well as enhances bioavailability (Hilty et al., 2010). Nanoparticles have higher surface activity, high catalytic efficacy, strong adsorbing ability and have extensive domino effect (Xu et al., 2003). Nanoselenium exhibits novel properties different from other selenium sources and possess equal efficacy compared to organic form of selenium. Similarly, the toxicity of nanoselenium is seven times lower than that of inorganic selenium and three times lower than that of organic selenium (Peng et al., 2007). Currently, nano elemental selenium (nanoSe), is used in nutritional supplements and has 
promising applications in medical therapy (Zhang et al., 2001 and Gao et al., 2002). Nanoselenium improved the growth performance, feed conversion efficiency (Zhou and Wang, 2011) and antioxidant enzyme activity (Cai et al., 2012) in broiler chickens. The range between optimal and toxic dietary levels of nanoselenium was wider than that of sodium selenite, and also, nanoselenium was more efficiently absorbed in the body than sodium selenite $(\mathrm{Hu}$ et al., 2012).

Furthermore, Zhang et al., (2005) reported that nanoSe possessed higher efficiency than selenite, selenomethionine, and methylselenocysteine (Zhang et al., 2008; Wang et $a l ., 2007)$ in upregulating selenoenzymes in mice and rats and exhibited lesser toxicity (Zhang et al., 2001).

Even though studies have conducted earlier to assess the effect of selenium in poultry, there is only little research done to study the influence of nanoselenium on growth performance of broiler chickens. Consequently, the aim of the present study was to determine the effects of dietary supplementation of nanoselenium on production performance of broiler chickens and to compare its efficacy with the inorganic and organic forms.

\section{Materials and Methods}

\section{Preparation and characterisation of nanoselenium}

Nanored selenium particles were synthesized as per the method described by Zhang et al., (2001) with slight modification using sodium selenite, starch, ascorbic acid and bovine serum albumin. The compositional analysis of the samples were studied based on the energy dispersive analysis of X-Rays using PANalytical X-Ray diffractometer (JEOL
Model JED-2300). Samples for transmission electron microscopy (TEM) analysis were prepared by drop-coating selenium nanoparticles solution on to carbon-coated copper TEM grids. Transmission electron micrographs were obtained on JEM- 2100F (JEOL Inc., Japan) instrument with an accelerating voltage of $80 \mathrm{kV}$.

A biological trial was conducted with one hundred and eighty numbers of day-old straight broiler chicks (Vencobb 400) obtained from commercial hatchery. The birds were wing banded, weighed and randomly allotted to six groups with three replicates of ten chicks each based on the body weight. The birds were reared in cages under uniform standard managemental practices upto six weeks of age.

Sodium selenite and Selplex ${ }^{\mathrm{TM}}$ (Alltech, USA) were used as inorganic and organic selenium supplement forms in the diets. The nanoselenium synthesized in the department of Veterinary Physiology, Veterinary College and research Institute Namakkal was used in the experimental diets. The size of the nanoselenium was found to lie in the range of $15-40 \mathrm{~nm}$ as characterised by $\mathrm{X}$ Ray diffractional analysis and Transmission electron microscopic studies. The diets were formulated according to the standards prescribed in Bureau of Indian Standards (BIS, 1992) and fed to the birds as per the following schedule.

Broiler prestarter, starter and finisher diets were fed ad libitum to the birds from 1 to 14 , 15 to 28 and 29 to 42 days of age, respectively. At the end of the experiment $\left(42^{\text {nd }}\right.$ day), six birds per treatment group were randomly selected and slaughtered. At the end of the experiment $\left(42^{\text {nd }}\right.$ day), six birds per treatment group were randomly selected and slaughtered by halal method. 


\section{Growth performance}

During the course of experiment the data on growth performance parameters viz., body weight, feed consumption and feed efficiency were collected as follows.

\section{Body weight (Weekly Cumulative)}

The body weights all the chicks were weighted individually on day one and at the end of each week. For entire six weeks of the trial the body weight gain was calculated.

\section{Feed consumption (Weekly cumulative)}

The feed consumption in each replicate was recorded weekly by subtracting the weight of residual feed from the total quantity of feed supplied during the respective week.

\section{Feed conversion ratio}

At the end of every week, feed intake was recorded and mean daily feed consumption per bird and feed conversion ratio of each group were calculated.

The feed conversion ratio (FCR) expressed as the relationship between amount of feed consumed $(\mathrm{kg})$ to the body weight gain $(\mathrm{kg})$ under each treatment of birds was determined. The FCR was calculated by using the following formula,

Feed conversion ratio $=\frac{\text { Average weekly feed consumption per bird during the week }(\mathrm{Kg})}{\text { Average body weight gain per bird during the week }(\mathrm{Kg})}$

\section{Statistical methods}

The completely randomized design method was followed for the experiment (Snedecor and Cochran, 1994) and the data collected were analysed using SPSS ${ }^{\circledR} 20.0$ software package. Post-hoc analysis was done by Tukey honestly significance difference test.

\section{Results and Discussion}

\section{Growth performance}

\section{Body weight gain}

The effect of supplementation of different sources of selenium on the mean body weight gain $(\mathrm{g})$ of broiler chicken from 1 to 6 weeks of age is presented in Table 1 and Fig. 1 .

The mean body weight gain $(\mathrm{g})$ recorded at the end of $6^{\text {th }}$ week were $2050.35,2108.40$, $2117.58,2136.50$ and 2141.65 for the groups T2 to T6, respectively when compared to 2030.60 of T1 group.

The mean body weight gain at the end of $6^{\text {th }}$ week was higher $(p<0.05)$ in the organic and nanoselenium supplemented groups compared to control. All the nanoselenium supplemented groups (T4, T5 and T6) showed significantly higher $(\mathrm{p}<0.05)$ body weight gain than $\mathrm{T} 1$ from $4^{\text {th }}$ week onwards. The T5 and T6 groups supplemented with nanoselenium at $0.3 \mathrm{mg} / \mathrm{kg}$ and $0.6 \mathrm{mg} / \mathrm{kg}$ showed significantly $(\mathrm{p}<0.05)$ increased body weight gain than the groups $\mathrm{T} 1, \mathrm{~T} 2, \mathrm{~T} 3$ and $\mathrm{T} 4$. The mean body weight gain of T3 did not differ from $\mathrm{T} 4$.

These findings are in agreement with Zhou and Wang (2011) and $\mathrm{Hu}$ et al., (2012) who observed that the final body weight and daily weight gain were significantly $(p<0.05)$ increased in broiler chickens supplemented with nanoselenium $(0.3 \mathrm{mg}$ to $0.6 \mathrm{mg} / \mathrm{kg})$.

Choct et al., (2004) and Upton et al., (2008) also reported an improved body weight and feed conversion ratio in broiler chicken fed organic selenium $(0.2 \mathrm{ppm})$ compared to broilers fed inorganic selenium $(0.2 \mathrm{ppm})$ and control group (no selenium supplementation). 
Table.1 Mean $( \pm$ SE) body weight gain $(\mathrm{g})$ of broiler chickens fed inorganic, organic and nanoselenium

\begin{tabular}{|c|c|c|c|c|c|c|}
\hline \multirow[t]{2}{*}{ Treatment groups } & \multicolumn{6}{|c|}{ Weekly body weight gain (g) } \\
\hline & I & II & III & IV & V & VI \\
\hline T1- standard diet & $94.37 \pm 1.80$ & $264.99^{\mathrm{a}} \pm 7.05$ & $618.23^{\mathrm{a}} \pm 12.36$ & $958.60^{\mathrm{a}} \pm 15.75$ & $1500.17^{\mathrm{a}} \pm 16.08$ & $2030.60^{\mathrm{a}} \pm 23.65$ \\
\hline $\begin{array}{c}\mathrm{T} 2 \text { - standard diet }+ \\
0.3 \mathrm{mg} \text { inorganic } \\
\mathrm{Se} / \mathrm{kg}\end{array}$ & $94.89 \pm 1.45$ & $273.17^{\mathrm{ab}} \pm 4.19$ & $626.82^{\mathrm{a}} \pm 11.45$ & $983.28^{\mathrm{ab}} \pm 9.81$ & $1518.18^{\mathrm{ab}} \pm 17.77$ & $2050.35^{\mathrm{ab}} \pm 13.39$ \\
\hline $\begin{array}{c}\text { T3 }- \text { standard diet }+ \\
0.3 \mathrm{mg} \text { organic Se } \\
\text { /kg }\end{array}$ & $95.28 \pm 1.73$ & $276.53^{\mathrm{ab}} \pm 4.95$ & $630.08^{\mathrm{a}} \pm 9.63$ & $1013.56^{\mathrm{bc}} \pm 8.76$ & $1566.66^{\mathrm{ab}} \pm 19.91$ & $2108.40^{b c} \pm 10.95$ \\
\hline $\begin{array}{l}\text { T4 - standard diet }+ \\
0.15 \mathrm{mg} \text { nanoSe } / \mathrm{kg}\end{array}$ & $96.19 \pm 1.22$ & $287.94^{\mathrm{bc}} \pm 5.15$ & $656.55^{\mathrm{ab}} \pm 8.19$ & $1022.92^{b c} \pm 14.36$ & $1588.58^{\mathrm{b}} \pm 20.80$ & $2117.58^{b c} \pm 17.42$ \\
\hline $\begin{array}{c}\text { T5 - standard diet + } \\
0.3 \mathrm{mg} \text { nanoSe } / \mathrm{kg}\end{array}$ & $98.65 \pm 1.38$ & $292.06^{\mathrm{bc}} \pm 3.96$ & $674.48^{\mathrm{b}} \pm 12.35$ & $1040.17^{c} \pm 14.91$ & $1684.47^{\mathrm{c}} \pm 21.79$ & $2136.50^{c} \pm 25.36$ \\
\hline $\begin{array}{l}\text { T6 - standard diet + } \\
0.6 \mathrm{mg} \text { nanoSe } / \mathrm{kg}\end{array}$ & $99.24 \pm 1.34$ & $300.18^{c} \pm 5.43$ & $679.95^{b} \pm 9.25$ & $1056.7^{c} \pm 14.96$ & $1686.30^{c} \pm 19.65$ & $2141.65^{\mathrm{c}} \pm 17.47$ \\
\hline
\end{tabular}


Table.2 Mean $( \pm$ SE) weekly and cumulative feed consumption $(\mathrm{g})$ of broiler chickens fed inorganic, organic and nanoselenium

\begin{tabular}{|c|c|c|c|c|c|c|c|}
\hline \multirow[t]{2}{*}{ Treatment groups } & \multicolumn{6}{|c|}{ Weekly feed consumption (g) } & \multirow{2}{*}{$\begin{array}{c}\text { Cumulative feed } \\
\text { consumption } \\
\text { (g) }\end{array}$} \\
\hline & I & II & III & IV & $\mathbf{V}$ & VI & \\
\hline T1- standard diet & $\begin{array}{l}91.93 \\
\pm 1.03\end{array}$ & $265.27 \pm 1.94$ & $474.63^{c} \pm 0.70$ & $654.23^{\mathrm{d}} \pm 2.28$ & $935.40^{\mathrm{c}} \pm 0.95$ & $1069.00^{\mathrm{e}} \pm 0.29$ & $3490.47^{\mathrm{d}} \pm 3.92$ \\
\hline $\begin{array}{c}\mathrm{T} 2 \text { - standard diet }+ \\
0.3 \mathrm{mg} \text { inorganic } \\
\mathrm{Se} / \mathrm{kg}\end{array}$ & $91.90 \pm .21$ & $260.47 \pm 4.32$ & $469.87^{\mathrm{ab}} \pm 0.84$ & $647.83^{d} \pm 0.60$ & $933.67^{b c} \pm 0.68$ & $1059.83^{\mathrm{d}} \pm 1.30$ & $3463.57^{\mathrm{d}} \pm 5.12$ \\
\hline $\begin{array}{c}\text { T3 - standard diet }+ \\
0.3 \mathrm{mg} \text { organic Se } \\
\text { /kg }\end{array}$ & $\begin{array}{l}89.97 \\
\pm 1.13\end{array}$ & $259.80 \pm 1.74$ & $469.80^{\mathrm{ab}} \pm 1.65$ & $626.53^{c} \pm 1.74$ & $923.83^{\mathrm{abc}} \pm 0.73$ & $1050.00^{c} \pm 1.44$ & $3419.93^{c} \pm 6.33$ \\
\hline $\begin{array}{l}\text { T4 - standard diet }+ \\
0.15 \mathrm{mg} \text { nanoSe } / \mathrm{kg}\end{array}$ & $\begin{array}{l}90.40 \\
\pm 1.95\end{array}$ & $256.60 \pm 0.45$ & $469.87^{\mathrm{ab}} \pm 0.84$ & $616.03^{b c} \pm 3.78$ & $920.37^{\mathrm{ab}} \pm 5.61$ & $1039.70^{b} \pm 3.21$ & $3392.97^{\mathrm{bc}} \pm 10.2$ \\
\hline $\begin{array}{l}\text { T5 - standard diet }+ \\
0.3 \mathrm{mg} \text { nanoSe } / \mathrm{kg}\end{array}$ & $\begin{array}{l}89.53 \\
\pm 1.16\end{array}$ & $255.40 \pm 1.80$ & $468.47^{\mathrm{a}} \pm 1.53$ & $607.23^{\mathrm{ab}} \pm 2.74$ & $913.60^{\mathrm{a}} \pm 3.95$ & $1038.53^{\mathrm{ab}} \pm 2.82$ & $3372.77^{\mathrm{ab}} \pm 7.68$ \\
\hline $\begin{array}{l}\text { T6 - standard diet + } \\
0.6 \mathrm{mg} \text { nanoSe } / \mathrm{kg}\end{array}$ & $\begin{array}{l}87.77 \\
\pm 0.37\end{array}$ & $255.73 \pm 1.88$ & $467.80^{\mathrm{a}} \pm 1.17$ & $605.07^{\mathrm{a}} \pm 0.58$ & $912.67^{\mathrm{a}} \pm 1.86$ & $1030.50^{\mathrm{a}} \pm 0.29$ & $3359.53^{\mathrm{a}} \pm 1.12$ \\
\hline
\end{tabular}


Table.3 Mean $( \pm$ SE) feed conversion ratio of broiler chickens fed inorganic, organic and nanoselenium

\begin{tabular}{|c|c|c|c|c|c|c|}
\hline \multirow{2}{*}{ Treatment groups } & \multicolumn{6}{|c|}{ Weekly feed conversion ratio } \\
\hline & $\mathbf{I}$ & II & III & IV & $\mathbf{V}$ & VI \\
\hline T1 - standard diet & $1.24 \pm 0.05$ & $1.35^{\mathrm{b}} \pm 0.06$ & $1.35^{\mathrm{b}} \pm 0.04$ & $1.55^{\mathrm{c}} \pm 0.05$ & $1.62^{c} \pm 0.03$ & $1.72^{\mathrm{b}} \pm 0.03$ \\
\hline $\mathrm{T} 2$ - standard diet $+0.3 \mathrm{mg}$ inorganic $\mathrm{Se} / \mathrm{kg}$ & $1.23 \pm 0.03$ & $1.29^{\mathrm{ab}} \pm 0.02$ & $1.31^{\mathrm{ab}} \pm 0.03$ & $1.50^{\mathrm{bc}} \pm 0.03$ & $1.58^{\mathrm{bc}} \pm 0.03$ & $1.69^{b} \pm 0.02$ \\
\hline $\mathrm{T} 3$ - standard diet $+0.3 \mathrm{mg}$ organic $\mathrm{Se} / \mathrm{kg}$ & $1.20 \pm 0.03$ & $1.27^{\mathrm{ab}} \pm 0.05$ & $1.30^{\mathrm{ab}} \pm 0.02$ & $1.43^{\mathrm{abc}} \pm 0.02$ & $1.51^{\mathrm{bc}} \pm 0.04$ & $1.62^{\mathrm{ab}} \pm 0.03$ \\
\hline $\mathrm{T} 4$ - standard diet $+0.15 \mathrm{mg}$ nanoSe $/ \mathrm{kg}$ & $1.17 \pm 0.04$ & $1.21^{\mathrm{ab}} \pm 0.03$ & $1.24^{\mathrm{ab}} \pm 0.02$ & $1.40^{\mathrm{ab}} \pm 0.03$ & $1.48^{\mathrm{ab}} \pm 0.02$ & $1.60^{\mathrm{ab}} \pm 0.04$ \\
\hline $\mathrm{T} 5$ - standard diet $+0.3 \mathrm{mg}$ nanoSe $/ \mathrm{kg}$ & $1.14 \pm 0.05$ & $1.18^{\mathrm{ab}} \pm 0.01$ & $1.21^{\mathrm{a}} \pm 0.02$ & $1.37^{\mathrm{a}} \pm 0.01$ & $1.39^{\mathrm{a}} \pm 0.04$ & $1.58^{\mathrm{ab}} \pm 0.03$ \\
\hline T6 - standard diet $+0.6 \mathrm{mg}$ nanoSe $/ \mathrm{kg}$ & $1.11 \pm 0.01$ & $1.15^{\mathrm{a}} \pm 0.05$ & $1.20^{\mathrm{a}} \pm 0.03$ & $1.34^{\mathrm{a}} \pm 0.01$ & $1.38^{\mathrm{a}} \pm 0.02$ & $1.57^{\mathrm{a}} \pm 0.02$ \\
\hline
\end{tabular}

Fig.1 Mean body weight gain (g) of broiler chickens fed inorganic, organic and nanoselenium

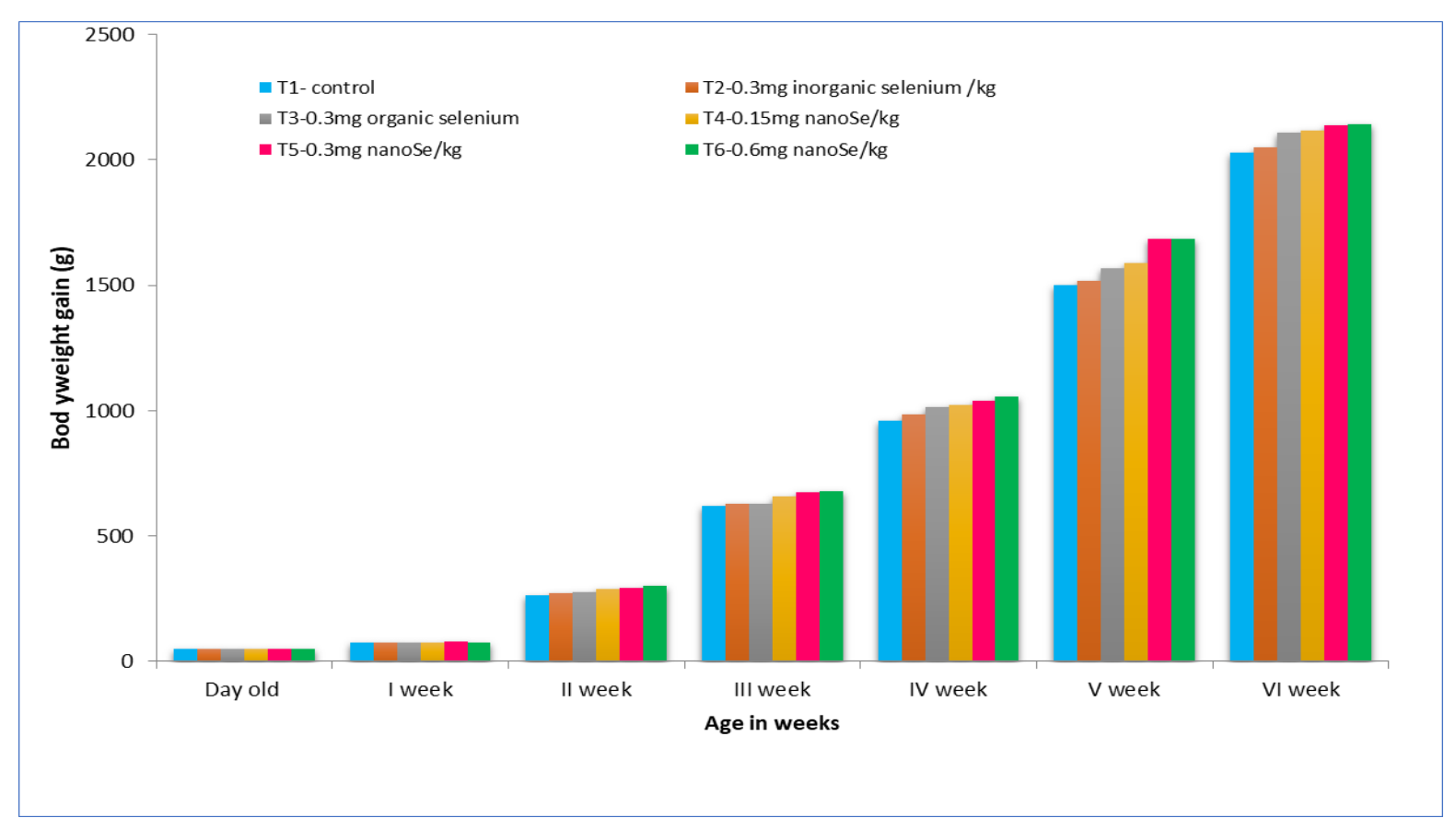


However, Cai et al., (2012) reported that there was no significant increase in growth performance in nanoselenium supplemented ( 0.3 to $2.0 \mathrm{mg} / \mathrm{kg}$ ) chicken. Similarly, Yoon et al., (2007) and Rao et al., (2013) reported no difference in body weight in comparison to control, when broiler chickens were fed diets containing 0.2 to $0.4 \mathrm{ppm}$ organic selenium.

Selenium is a component of glutathione peroxidase enzyme (GSH-Px) (Rotruck et al., 1973), which is an antioxidant enzyme that catalyzes the reduction of hydrogen peroxide and lipid hydroperoxides and thereby destroys the free radicals produced during normal metabolic activity. Selenium participates in various physiological functions, mostly as an integral component of a range of selenoproteins. Selenoproteins play an important role in thyroid hormone metabolism. Iodothyronine deiodinases (ID) are selenoenzymes responsible for converting the inactive thyroxine (T4) into an active form -3,5,3'-triiodothyronine (T3) (Arthur et al., 1990). Thyroid hormones play an important role in growth and protein turnover. The level of selenium affects the growth of chickens via thyroid hormone metabolism. Dietary selenium supplementation increased plasma $\mathrm{T}_{3}$, whereas decreased $\mathrm{T}_{4}$. Hepatic 5, deiodinase activity was elevated by selenium (Schmidt and Reavill, 2008).

Selenium is essential for the optimum functioning of the immune system. It has beneficial effects on both the innate and adaptive (cell mediated and antibody mediated) immune responses (Brown and Arthur, 2001) and influences the immune system at several mechanistic levels. Selenium via selenoproteins influences inflammatory responses by regulating the oxidative state of immune cells. Not only does the immune system rely on the antioxidant properties of $\mathrm{Se}$ to control oxidative bursts by phagocytic cells, it also has specific endocrine effects that benefit antibody-mediated immunity. Lymphocyte proliferation was enhanced by $\mathrm{Se}$ supplementation due to the role of Se in the modulation of the arachidonic acid metabolism (Cao et al., 1992).

Thus, the significantly increased body weight in the nanoselenium supplemented broiler chickens in the present study could be related to the higher antioxidant status, higher $T_{3}$ hormone, increased $\mathrm{T}_{3} / \mathrm{T}_{4}$ activation ratio, and immune status, in these groups compared to the control.

\section{Feed Consumption and Feed Conversion Ratio}

The effect of inorganic, organic and nanoselenium supplementation on the mean weekly and cumulative feed consumption and feed efficiency of broiler chickens from 1 to 6 weeks of age are presented in Table 2 and 3.

The mean weekly feed consumed $(\mathrm{g})$ recorded at the end of first two weeks did not differ significantly between the unsupplemented and selenium supplemented groups. The mean cumulative feed consumed $(\mathrm{g})$ at the end of $6^{\text {th }}$ week was $3463.57,3419.93,3392.97$, 3372.77 and 3359.53 for the groups T2 to T6, respectively when compared to 3490.47 in group T1.

The mean cumulative feed consumption of nanoselenium supplemented groups (T4, T5 and T6) was significantly $(\mathrm{p}<0.05)$ decreased in comparison to control, inorganic and organic selenium supplemented birds. Moreover, throughout the trial period the weekly feed consumption of $0.6 \mathrm{mg} / \mathrm{kg}$ nanoselenium supplemented group (T6) was significantly $(\mathrm{p}<0.05) \quad$ decreased when compared to all other treatment groups and control. The feed consumption of T3 and T4 decreased significantly $(\mathrm{p}<0.05)$ from $\mathrm{T} 1$ and $\mathrm{T} 2$. 
The mean feed conversion ratio at the end of $6^{\text {th }}$ week was $1.69,1.62,1.60,1.58$ and 1.57 in the treatment groups T2 to T6, respectively as compared to 1.72 in the control birds.

The mean feed efficiency was better in 0.6 $\mathrm{mg} / \mathrm{kg}$ nano Se chickens in comparison to inorganic selenium groups and control. However, the feed efficiency did not differ in the birds supplemented with either inorganic selenium or those without any selenium supplementation. Similarly, the feed efficiency did not differ in the organic and nanoselenium $(0.15$ and $0.3 \mathrm{mg} / \mathrm{kg})$ supplemented chickens.

These results concurred with the findings of Zhou and Wang (2011) and Hu et al., (2012) who reported that the feed efficiency was better in chickens supplemented with 0.3 $\mathrm{mg} / \mathrm{kg}$ and $0.5 \mathrm{mg} / \mathrm{kg}$ of nanoselenium. Similarly, Deniz et al., (2005) and Naylor and Choct (2000) observed improved $(p<0.01)$ feed conversion ratio from the $1^{\text {st }}$ to the $42^{\text {nd }}$ day when broiler birds were supplemented with $0.25 \mathrm{ppm}$ of organic Se in comparison to sodium selenite supplemented groups and control.

On the contrary, Cai et al., (2012) reported no change in the feed efficiency in the chickens supplemented with nanoselenium. Payne and Southern (2005) and Peric et al., (2009) also observed insignificant effect by selenium supplementation on feed efficiency in broiler chickens.

The decrease in feed consumption and improved feed efficiency in nanoselenium and organic selenium supplemented groups could be attributed to the marked hypercellularity and increase in the intestinal villi length and width when compared to the other groups. This increase in the intestinal epithelial surface area would have aided in enhanced absorption and assimilation of nutrients in the gastrointestinal tract, thus finally contributing to better growth performance seen in these birds.

In conclusion, selenium is pharmacologically active and optimisation of selenium nutrition of poultry will result in increased efficiency of egg and meat (Surai, 2000). The form of selenium influences the bioavailability and activity. Selenium nanoparticles show special characteristics of transport, exhibit higher absorption efficiencies and function. Thus, it could be concluded that the mean body weight gain (g) of broiler chicken supplemented with nano $\mathrm{Se}$ at $0.15,0.3$ and $0.6 \mathrm{mg} / \mathrm{kg}$ was significantly $(\mathrm{p}<0.05)$ increased than the control birds. Chickens supplemented with nanoselenium at 0.15 $\mathrm{mg} / \mathrm{kg}$ and $0.3 \mathrm{mg} / \mathrm{kg}$ of organic selenium had similar body weight gain. Increasing the nanoselenium supplementation from 0.3 to $0.6 \mathrm{mg} / \mathrm{kg}$ did not cause any further increase in the body weight gain. Overall, the nanoselenium supplemented in the range $0.15-0.6 \mathrm{mg} / \mathrm{kg}$ increased body weight gain of broiler chickens significantly $(p<0.05)$ when compared to the control birds.

The mean cumulative feed consumption of all the nanoselenium supplemented groups was significantly $(\mathrm{p}<0.05)$ decreased in comparison to control and inorganic selenium supplemented birds. The mean feed efficiency was better in $0.6 \mathrm{mg} / \mathrm{kg}$ nanoSe chickens in comparison to inorganic selenium groups and control. The mean feed efficiency was better in organic and nanoselenium supplemented chickens than the control and the $0.6 \mathrm{mg} / \mathrm{kg}$ nanoselenium supplemented group showed highly efficient feed conversion.

\section{Acknowledgement}

The authors wish to thank the Dean, Veterinary College and Research Institute, Namakkal and Tamil Nadu Veterinary and Animal Sciences University for providing necessary funds and research facilities to carry out the study. 


\section{References}

Arner, E.S. and Holmgren, A. 2000. Physiological functions of thioredoxin and thioredoxin reductase. Eur. $J$. Biochem., 267: 6102-6109.

Arthur, J.R., Nicol. F and Beckett, G.J. 1990. Hepatic iodothyronine 5'deiodinase. The role of selenium. Biochem. J., 272: 537-540.

Brown, K.M. and Arthur, J.R. 2001. Selenium, selenoproteins and human health: a review. Public Health Nutr., 4: 593-599.

Cai, S.J., Wu, C.X., Gong, L.M., Song, T., $\mathrm{Wu}, \mathrm{H}$ and Zhang, L.Y. 2012. Effects of nanoselenium on performance, meat quality, immune function, oxidation resistance, and tissue selenium content in broilers. Poult. Sci., 91: 2532-2539.

Cao, Y.Z., Maddox, J.F., Mastro, A.M., Scholz, R.W., Hildenbrandt, G. and Reddy, C.C. 1992. Selenium deficiency alters the lipoxygenase pathway and mitogenic response in bovine lymphocytes. J. Nutr., 122: 2121-2127.

Choct, M., Naylor, A.J. and Reinke, N. 2004. Selenium supplementation affects broiler growth performance, meat yield, and feather coverage. Br. Poult. Sci., 45: 677-683.

Deniz, G., Gezen, S.S. and Turmen, I.I. 2005. Effects of two supplemental dietary selenium sources (mineral and organic) on broiler performance and drip loss. Revue. Med. Vet., 8: 423-426.

FDA. 2002. Food additive permitted in feed and drinking water: Selenium yeast. Federal Register, 67: 46850-46851.

Gao, X.Y., Zhang, J. and Zhang, L. 2002. Hollow sphere selenium nanoparticles: their in vitro anti hydroxyl radical effect. Adv. Mater., 14: 290-293.

Godin, D.V. and Wohaieb, S.A. 1988. Nutritional deficiency, starvation, and tissue antioxidant status. Free Radical Biol. Med., 5: 165-176.
Hilty, F.M., Arnold, M., Hilbe M., Teleki, A., Knijnenburg, J.T.N., Ehrensperger, F., Hurrell, R.F., Pratsinis, S.E., Langhans, W. and Zimmermann, M.B. 2010. Iron from nanocompounds containing iron and zinc is highly bioavailable in rats without tissue accumulation. Nature Nanotechnol., 5: 374-380.

Hu, C.H., Li, Y.L., Xiong, L., Zhang, H.M., Song, J. and Xia, M.S. 2012. Comparative effects of nano elemental selenium and sodium selenite on selenium retention in broiler chickens. Anim. Feed Sci. Tech., 177: 204- 210.

Morrissey, P.A. and O'Brien, N.M. 1998. Dietary antioxidants in health and disease. Int. Dairy J., 8: 463-472.

Naylor, A.J. and Choct, M. 2000. Effect of selenium source and level on performance mortality and meat quality in male broilers. Proc. Aust .Poult. Sci. Sym., 12:125-128.

NRC. 1994. Nutrient Requirements of Poultry. $9^{\text {th }}$ Edn, Washington DC., National Academy Press. pp 44-45.

Payne, R.L. and Southern, L.L. 2005. Comparison of inorganic and organic selenium sources for broiler. Poult. Sci., 84: 898-902.

Peng, D., Zhang, J., Liu, Q. and Taylor, E.W. 2007. Size effect of elemental selenium nanoparticles (Nano-Se) at supra nutritional levels on selenium accumulation and glutathione Stransferase activity. J. Inorg. Biochem., 101: 1457-1463.

Peric, L., Milosevic, N., Zikic, D., Kanacki, Z., Dzinic, N., Nollet, L. and Spring, P. 2009. Effect of selenium sources on performance and meat characteristics of broiler chickens. J. Appl. Poult. Res., 18: 403-409.

Rao, S.V., Prakash, B., Raju, M.V.N. and Arun Kumar, P. 2013. Effect of supplementing organic selenium on performance, carcass traits, oxidative 
parameters and immune responses in commercial broiler. Asian-Aust. J. Anim. Sci., 26: 247-252.

Rotruck, J.T., Pope, A.L., Ganther, H.E., Swanson, A.B., Hafeman, D.G. and Hoekstra, W.G. 1973. Selenium: Biochemical role as a component of glutathione peroxidase. Science, 179: 588-590.

Schmidt, R.E. and Reavill, D.R. 2008. The avian thyroid gland. Vet. Clin. North Am. Exot. Anim. Pract., 11: 15-23.

Schrauzer, G.N. 2003. The nutritional significance, metabolism and toxicology of selenomethionine. Adv. Food Nutr. Res., 47: 73-112.

Snedecor, G.M. and Cochran, W.C. 1994. Statistical Methods. $9^{\text {th }}$ Edn. Oxford and IBM Publishing Company, Mumbai, India.

Surai, P.F. 2000. Organic selenium: benefits to animals and humans, a biochemist's view. In: T.P. Lyons and K.A. Jacques (Eds.) Biotechnology in the Feed industry. Proc. of Alltech's 16th Annual Symposium. Nottingham University Press, Nottingham, UK, pp.205-260.

Upton, J.R., Edens, F.W. and Ferket, P.R. 2008. Selenium yeast effect on broiler performance. Int. J. Poult. Sci., 7: 798805.

Wang, H., Zhang, J. and Yu, H. 2007. Elemental selenium at nano size possesses lower toxicity without compromising the fundamental effect on selenoenzymes: comparison with selenomethionine in mice. Free Radical Biol. Med., 42: 524-533.
Waschulewski, I.H. and Sunde, R.A. 1988. Effect of dietary methionine on tissue selenium and glutathione peroxidase activity in rats given selenomethionine. Br.J. Nutr., 60: 57-68.

Xu, B.H., Xu, Z.L. and Xia, M.S. 2003. Effect of nano red elemental selenium on GPX activity of broiler chick kidney cells in vitro. Wuhan Univ. J.Nat. Sci., 8: 11671172.

Yoon, I., Werner, T.M. and Butler, J.M. 2007. Effect of source and concentration of selenium on growth performance and selenium retention in broiler chickens. Poult. Sci., 86: 727-730.

Zhang, J.S., Gao, X.Y., Zhang, L.D. and Bao, Y.P. 2001. Biological effects of a nano red elemental selenium. Biofactors, 15: 27-38.

Zhang, J.S., Wang, H.L., Yan, X.X. and Zhang, L.D. 2005. Comparison of short term toxicity between Nano-Se and selenite in mice. Life Sci., 76: 10991109.

Zhang, J., Wang, X. and Xu, T. 2008. Elemental selenium at Nano Size (Nano-Se) as a potential chemopreventive agent with reduced risk of selenium toxicity: comparison with Se-Methylselenocysteine in mice. Toxicol. Sci., 101: 22-31

Zhou, X. and Wang, Y. 2011. Influence of dietary nano elemental selenium on growth performance, tissue selenium distribution, meat quality and glutathione peroxidase activity in Guangxi yellow chicken. Poult. Sci., 90: 680-686.

\section{How to cite this article:}

Visha, P., P. Selvaraj and Jayachandran, S. 2020. Nanoselenium as a Growth Promoting Feed Supplement in Broiler Chickens. Int.J.Curr.Microbiol.App.Sci. 9(05): 3247-3257. doi: https://doi.org/10.20546/ijcmas.2020.905.385 